\title{
ADSORPSI EOSIN Y DARI LARUTAN BERAIR DENGAN MENGGUNAKAN KOLUM KITOSAN HIDROKSIAPATIT
}

\section{Erdawati}

Jurusan Kimia, Fakultas MIPA, Universitas Negeri Jakarta, Jl. Pemuda No 10, Rawamangun 13220, Jakarta, Indonesia

Email : erda_warti_0912@yahoo.com

\begin{abstract}
Abstrak
Hidroksiapatit dibua dengan metode basah menggunakan larutan $\mathrm{Ca}(\mathrm{OH})_{2}$ dan $0,6 \mathrm{M}$ dan $\mathrm{H}_{3} \mathrm{PO}_{4} 1 \mathrm{M}$ pada $\mathrm{pH}$ 10. Selanjutnya hidroksiapatit dicampur dengan kitosan sehingga diperoleh hidroksiapatit kitosan.Berdasarkan hasil analisa FTIR menunjukkan bahwa reaksi antara hidroksiapatit dan kitosan melibatkan gugus fosfat dari hidroksiapatit dan gugus amina dari kitosan. Kitosan hidrksiapatit digunakan sebagai adsorben untuk mengadsorpsi Eosin $Y$ dengan metode kolum pada tinggi adsorben dan laju alir Eosin $Y$ yang berbeda beda. Model breakthrough diuji dengan menggunakan model perhitungan Yoon dan Nelson. Hasil yang diperoleh menunjukkan bahwa kapasitas adsorpsi terbesar diperoleh pada laju alir 0,2 mL/menit, tringgi adsorben $0,4 \mathrm{~cm}$ dan $\mathrm{pH}$ larutan Eosin $\mathrm{Y}=5$
\end{abstract}

Kata kunci : kitosan hidroksiapatit, adsoprsi , metode kolum, Eosin Y

\section{Pendahuluan}

Limbah pewarna organik merupakan salah satu masalah utama pencemaran air di berbagai industri seperti tekstil, kertas, plastik, kulit,makanan, kosmetik, dan lain-lain [1]. Zat warna bersifat stabil dan tahan degradasi terhadap waktu, sinar matahari dan perlakuan biologi maupun kimia. Limbah cair yang mengandung sejumlah kecil zat warna bisa sangat mempengaruhi kehidupan akuatik karena dapat mengurangi cahaya yang masuk ke dalam air dan beracun[2]. Berbagai metode penghilangan zat warna telah dikaji dan dikembangkan meliputi metode fisika, kimia, kimia-fisika dan biologi[3].

Adsorpsi merupakan salah satu metode kimia-fisika yang paling populer dan efektif untuk menghilangkan zat warna. Salah satu adsorben yang paling banyak digunakan adalah karbon aktif karena kapasitas adsorpsi yang tinggi untuk senyawa organik. Namun, karbon aktif mahal dan sulit untuk diperbaharui. Oleh karena itu perlu dikembangkan adsorben yang murah dan dapat diperbaharui untuk menghilangkan zat warna, seperti bahan-bahan alami, dan bahan limbah dari industri dan pertanian [4]. Terdapat berbagai bahan adsorben alami yang menarik, seperti kitosan, mineral tanah liat yang memiliki kemampuan yang tinggi untuk mengadsorpsi berbagai jenis zat warna. Kitosan bersifat ramah lingkungan dan

merupakan polisakarida tidak beracun yang berasal dari deasetilasi kitin, memilki afinitas yang sangat tinggi untuk berbagai jenis zat warna [5]. Kitosan lebih selektif daripada resin pernukar ion konvensional dan karbon aktif komersial,selain itu kitosan juga dapat mengurangi konsentrasi bahan pewarna sampai tingkat ppb. Jenis adsorben lain yang menarik adalah tanah liat, seperti kaolinit, smektit, dan Zeolit[6].

Sejalan dengan perkembangan teknologi nano, para peneliti mengembangkan adsorben dalam ukuran nano. Berbagai jenis nanosorben telah digunakan untuk mengadsorpsi zat warna dan ion logam seperti nanopartikel kitosan[7], nanomagnetik kitosan, [8], nanopartikel Zink oksidakitosan[9], nano kitosan hidroksiapatit [10], nanopartikel montmorilonit magnetite [11].

Proses adsorpsi dapat dilakukan secara batch dan secara kolum. Dengan metode kolum dapat ditentukan waktu dan volume limbah yang dapat diolah pada saat adsorben mulai jenuh. Metode kolum telah digunakan 


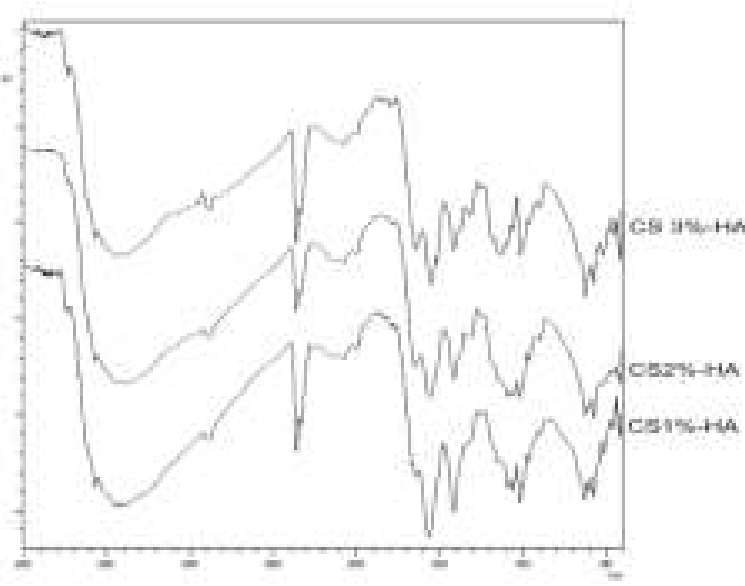

Gambar 1. Spektra FTIR kitosan Hidroksiapatit

untuk mengadsorpsi Reactive Black 5 [12], ion $\mathrm{Cu}^{+2}[13,14]$ dan ion $\mathrm{Cr}^{+6}[12]$. Pada penelitian ini metode kolum digunakan untuk mengadsorpsi Eosin $\mathrm{Y}$ dari larutan berair dengan menggunakan kitosan hidroksiapatit

\section{Percobaan}

\subsection{Alat dan bahan yang diperlukan}

Bahan yang diperlukan $\mathrm{Ca}(\mathrm{OH})_{2}, \mathrm{H}_{3} \mathrm{PO}_{4}$, $\mathrm{NH}_{4} \mathrm{OH}$, kitosan, larutan buffer dan Eosin Y.Alat yang digunakan dalam penelitian ini adalah neraca analitik (Wiggen), alat-alat gelas seperti batang pengaduk, spatula, corong kaca, kolom dengan diameter $20 \mathrm{~mm}$ dan tinggi $180 \mathrm{~mm}$, gelas kimia $100 \mathrm{~mL}$, dan gelas ukur $100 \mathrm{~mL}$, botol akuades, hotplate magnetik stirrer, magnetic bar, oven, sarung tangan, sikat pembersih, dan $\mathrm{pH}$ meter.

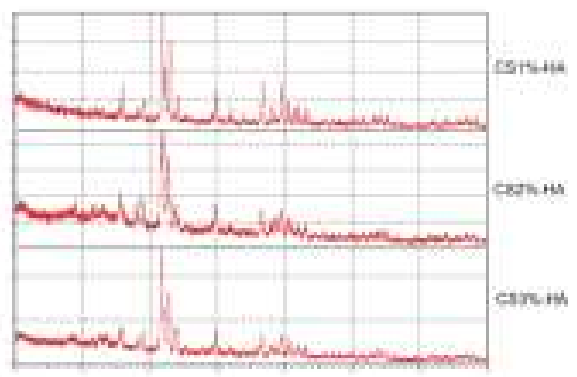

Gambar 2 . Difraksi sinar X dari komposit kitosanhidroksiapatit
Sedangkan instrumen yang digunakan untuk menganalisis zat warna Eosin $Y$ adalah spektrofotometer UV-Vis (Shimadzu), Fourier Transform Infra Red (FTIR) untuk menganalisis gugus fungsi kitosan-hidroksi apatit, X-Ray Diffraction (XRD) (Shimadzu) untuk menganalisis struktur kristal kitosan-hidroksi apatit, dan Field Emission Scanning Electron Microscopy (FESEM) untuk melihat bentuk permukaan kitosan-hidroksiapatit.

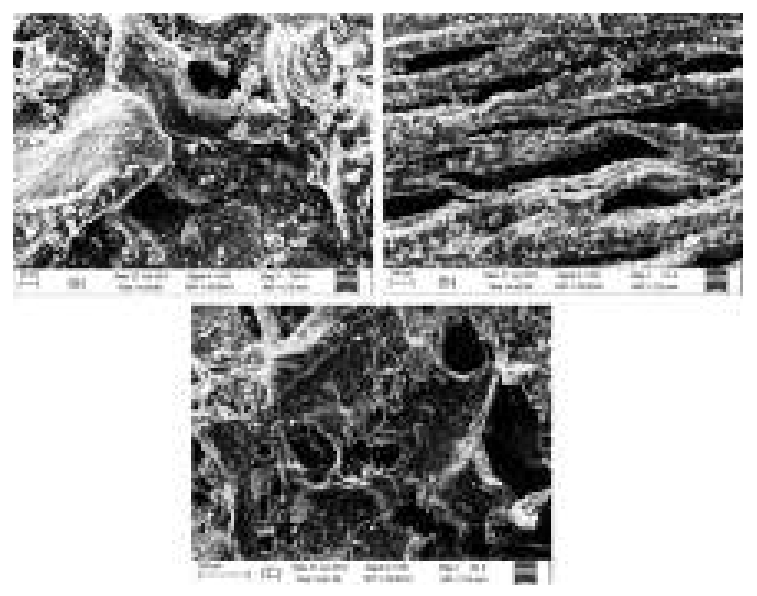

Gambar 3. Morfologi permukaan komposit kitosanhidroksiapatit dengan berbagai konsentrasi kitosa menggunakan scanning electron microscope (SEM) (a) $1 \%$ (b) $2 \%$ dan (c) $3 \%$

\subsection{Pembuatan Hidroksiapatit}

Hidroksiapatit dibuat dengan metode presipitasi dengan mencampurkan $500 \mathrm{~mL}$ larutan $\mathrm{Ca}(\mathrm{OH})_{2}$ 0,6M dengan $500 \mathrm{~mL}$ larutan $\mathrm{H}_{3} \mathrm{PO}_{4} 1 \mathrm{M}$ sambil diaduk selama 24 jam dengan pengaduk magnet. Kemudian $\mathrm{pH}$ larutan dinaikkan sampai $\mathrm{pH} 10$ dengan menambahkan $\mathrm{NH}_{4} \mathrm{OH} 25 \%$ setetes demi setetes. Endapan hidroksiapatit yang terbentuk kemudian dicuci dengan akuades sampai $\mathrm{pH}$ filtrat menjadi 7 , dikeringkan pada suhu $80^{\circ} \mathrm{C}$, kemudian dikalsinasi pada suhu $400^{\circ} \mathrm{C}$. Hidroksiapatit kemudian ditumbuk untuk menghasilkan serbuk

\subsection{Pembuatan Kitosan Hidroksiapatit}

Sebanyak 2 gram hidroksiapatit dicampurkan dengan $10 \mathrm{~mL}$ larutan kitosan 2\% 


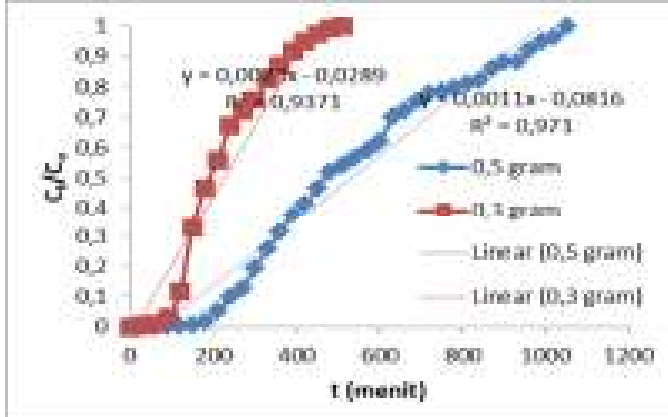

Gambar 4. Pengaruh tingi adsorben pada laju alir $0,2 \mathrm{~mL} / \mathrm{menit}$ dan konsentrasi Eosin Y $500 \mathrm{mg} / \mathrm{L}$

dalam asam asetat 1\%. Campuran diaduk selama 2 jam dengan menggunakan pengaduk magnet dan kemudian dikeringkan dalam oven pada suhu $80^{\circ} \mathrm{C}$. Kemudian dikalsinasi selama 1 jam pada suhu $500^{\circ} \mathrm{C}$

\subsection{Studi Kolum}

Pada percobaan ini digunakan kolum kaca dengan ukuran diameter dalam $1 \mathrm{~cm}$ dan tinggi kolum $30 \mathrm{~cm}$. Kolum diisi dengan manik kaca kemudian diisi dengan kitosan hidroksiapatit.

Tinggi adsorben yang digunakan bervariasi masing masing 0,2 dan $0,4 \mathrm{~cm}$, sementara konsentrasi Eosin $\mathrm{Y} 400 \mathrm{mg} / \mathrm{L}$ dan $\mathrm{pH}$ disesuaikan menjadi 5 .Effluen sampel dikumpulkan pada waktu tertentu dengan interval 30 menit. Konsentrasi Eosin $Y$ dalam effluent diukur dengan menggunakan spektrofotometer UV Vis pada panjang gelombang $517 \mathrm{~nm}$.

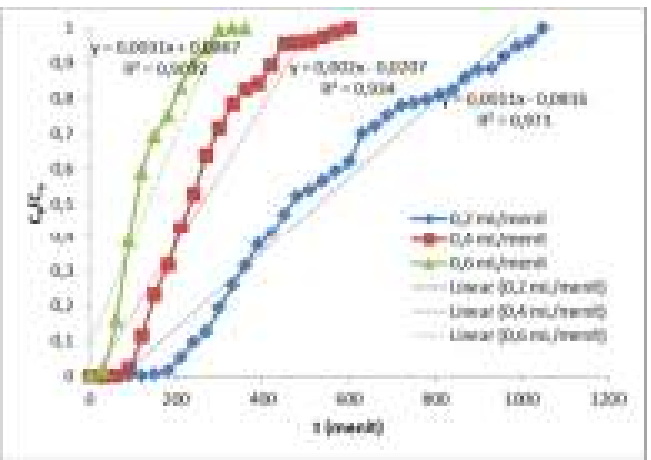

Gambar 5. Pengaruh laju alir ( $\mathrm{mL} / m e n i t)$ terhadap kurva breakthrough untuk mengadsorpsi Eosin $\mathrm{Y}$ pada ketinggian adsorben $0,3 \mathrm{~cm}$ dan konsentrasi Eosin Y $500 \mathrm{mg} / \mathrm{L}$

\subsubsection{Pengaruh tinggi adsorben}

Pengaruh tinggi adsorben terhadap banyaknya Eosin $\mathrm{Y}$ yang dapat dihilangkan dilakukan dengan memvariasikan tinggi adsorben masing masing $0,2 \mathrm{Cm}$ dan $0,4 \mathrm{Cm}$

\subsubsection{Pengaruh laju alir}

Pengaruh laju alir Eosin $Y$ terhadap banyaknya Eosin $Y$ yang dapat dihilangkan dilakukan uji dengan menggunakan laju alir $0.20 \mathrm{~mL} /$ menit $\quad 0.40 \mathrm{~mL} /$ menit dan 0,6 $\mathrm{mL} /$ menit dengan ketinggian adsorben $0,3 \mathrm{Cm}$

Tabel 1 Data hasil percobaan pada berbagai laju alir dan tinggi adsorben

\begin{tabular}{|c|c|c|c|c|}
\hline $\begin{array}{c}\text { Laju alir } \\
(\mathrm{mL} / \text { menit })\end{array}$ & $\begin{array}{c}\text { Tinggi } \\
\text { adsorben } \\
(\mathrm{cm})\end{array}$ & $\begin{array}{c}\text { qtotal } \\
(\mathrm{mg})\end{array}$ & $\begin{array}{c}\text { Veff } \\
(\mathrm{mL})\end{array}$ & $\begin{array}{c}\text { Total Cu } \\
\text { removal } \\
(\%)\end{array}$ \\
\hline 0,2 & 0,2 & 134 & 470 & 83 \\
\hline 0,2 & 0,4 & 155 & 485 & 86 \\
\hline 0,4 & 0,2 & 250 & 490 & 92 \\
\hline 0,4 & 0,4 & 250 & 490 & 93 \\
\hline 0,6 & 0,2 & 174 & 485 & 93 \\
\hline 0,6 & 0,4 & 112 & 485 & 54 \\
\hline
\end{tabular}

\subsection{Analisa data kolum}

Data yang diperoleh ditunjukkan dengan kurva breaktrough yang menggambarkan hubungan antara waktu dengan $\mathrm{Ce} / \mathrm{Co}$ pada berbagai lajur alir dan berbagai berat adsorben. Kurva breaktrough ini digunakan untuk menghitung waktu saat breaktrhrough (tb) yaitu waktu yang diperlukan untu kmenghilangkan Eosin $Y$ sebanyak 20\% dan waktu exhaust(te) yaitu waktu yang diperlukan untuk menghilangkan Eosin y sebesar 99\% [16].

\section{Hasil dan Pembahasan}

3.1 Karakterisasi Kitosan Hidroksiapatit

\subsubsection{Analisa FTIR}

Dalam kajian ini analisa FTIR digunakan untuk mengetahui gugus fungsi dari kitosan hidroksiapatit. Data spektroskopi IR menunjukkan pita serapan pada panjang 
Tabel 1. Nilai $k_{y N}$ dan $q_{0}$ pada berbagai tinggi adsorben dan berbagai laju alir

\begin{tabular}{|c|c|c|c|c|c|}
\hline $\begin{array}{c}\text { Tinggi } \\
\text { adsorben } \\
(\mathrm{cm})\end{array}$ & $\begin{array}{c}\text { Laju } \\
\text { alir } \\
(\mathrm{mL} / \\
\mathrm{mnt})\end{array}$ & $\begin{array}{c}\sigma \\
(\mathrm{mnt})\end{array}$ & $\begin{array}{c}\mathrm{K}_{\mathrm{Yn}} \\
\left(\mathrm{mnt}^{-1}\right)\end{array}$ & $\mathrm{R}^{2}$ & $\begin{array}{c}\mathrm{q}_{\circ} \\
(\mathrm{mg} / \mathrm{g})\end{array}$ \\
\hline 0.2 & 0.2 & 605 & 0.009 & 0.73 & 85.88 \\
\hline & 0.4 & 298 & 0.016 & 0.73 & 82.34 \\
\hline & 0.6 & 125 & 0.021 & 0.851 & 76.80 \\
\hline 0.3 & 0.2 & 724 & 0.0118 & 0.816 & 99.62 \\
\hline & 0.4 & 400 & 0.0421 & 0.816 & 90.73 \\
\hline & 0.6 & 237 & 0.0816 & 0.816 & 85.59 \\
\hline
\end{tabular}

elombang $1000 \mathrm{~cm}^{-1}-1100 \mathrm{~cm}^{-1}$ dan $500 \mathrm{~cm}^{-1}$ $600 \mathrm{~cm}^{-1}$ menunjukkan serapan gugus fungsi $\mathrm{PO}_{4}$ dari hidroksiapatit. Pita serapan yang meluas pada kisaran $1050 \mathrm{~cm}^{-1}$ menunjukkan keberadaan polimer dan interaksinya terhadap gugus $\mathrm{PO}_{4}$. Pita serapan sekitar $1450 \mathrm{~cm}^{-1}$ menunjukkan keberadaan ion karbonat. Pada pita serapan $1550 \mathrm{~cm}^{-1}-1700 \mathrm{~cm}^{-1}$ menunjukkan superposisi dari gugus $\mathrm{OH}$ hidroksiapatit dan amida dari kitosan. Pita serapan pada $3600 \mathrm{~cm}^{-}$ 1 - $3700 \mathrm{~cm}^{-1}$ dan $2800 \mathrm{~cm}^{-1}-2950 \mathrm{~cm}^{-1}$ menunjukkan serapan dari gugus $\mathrm{OH}$ pada kitosan. Vibrasi regang fospat pada hidroksiapatit terlihat pada $1000 \mathrm{~cm}^{-1}-1100 \mathrm{~cm}^{-}$ ${ }^{1}$ dan vibrasi lentur fospat terlihat pada $500 \mathrm{~cm}^{-}$ ${ }^{1}-600 \mathrm{~cm}^{-1}$. Karakter ion karbonat yang dominan terlihat pada pita serapan $1420 \mathrm{~cm}^{-1}$. $1485 \mathrm{~cm}^{-1}$

\subsubsection{Analisa XRD}

Kekristalan

komposit kitosan-

hidroksiapatit diamati dengan melihat karakteristiknya dengan difraktometer sinar $\mathrm{X}$. Komposit dengan komposisi kitosan berbeda memiliki karakter difraksi sinar $\mathrm{X}$ seperti yang ditunjukkan pada Gambar 2. Dengan meningkatnya konsentrasi kitosan menyebabkan puncak pada 25,879, 31,773, $32,196,32,902$, dan 49,468 yang menunjukkan karakteristik hidroksiapatit berkurang, dikarenakan sifat kitosan yang semikristal.

\subsubsection{Morfologi Permukaan}

Untuk melihat morfologi permukaan pada komposit kitosan-hidroksiapatit digunakan scanning electron microscope. Gambar dibawah ini menunjukkan mikrostruktur dari komposit kitosan-hidroksiapatit dengan berbagai konsentrasi kitosan (1\%, 2\% dan 3\%). Pada konsentrasi kitosan $1 \%$ pori-pori yang terbentukdenganpanjangsekitar 10 sampai 25 $\mu \mathrm{m}$, ukuran pori ini dipengaruhi karena kurang kokohnya material penyusun komposit sehingga pada saat perendaman komposit dalam larutan natrium sulfit $5 \%$ terjadi penyusutan. Sedangkan pada kitosan $2 \%$ pori yang terbentuk lebih besar dengan panjang sekitar 200-500 $\mu \mathrm{m}$, peningkatan kadar

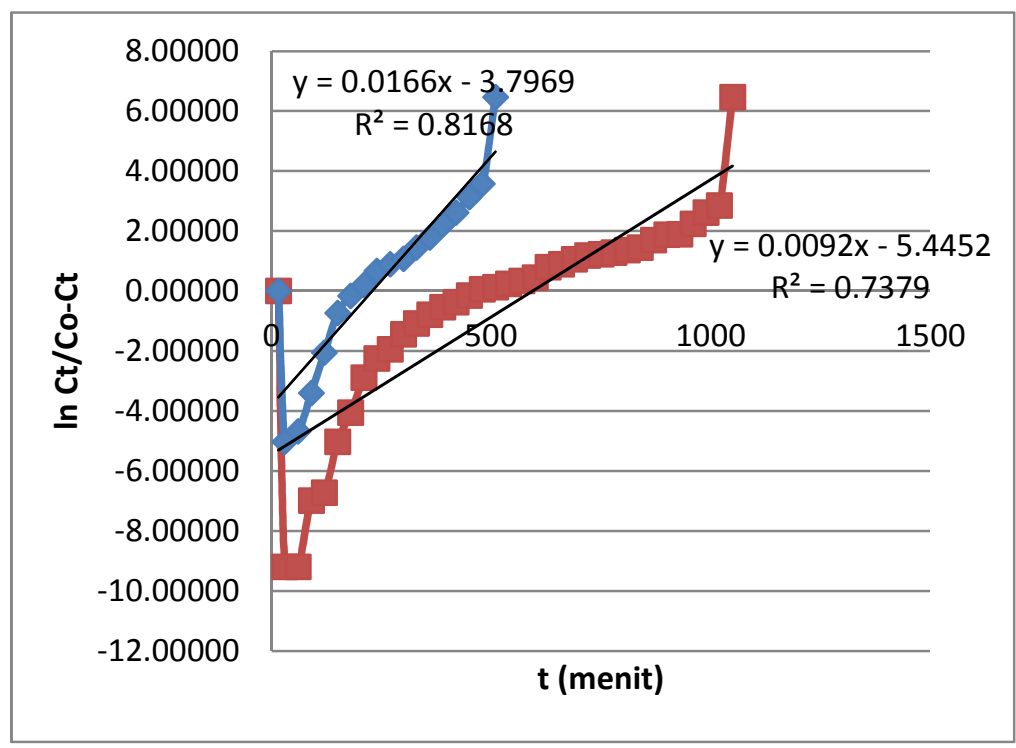

Gambar 6. Kurva hubungan $\ln \left(C_{t} / C_{o}-C t\right)$ Versus t pada berbagai tinggi adsorben 


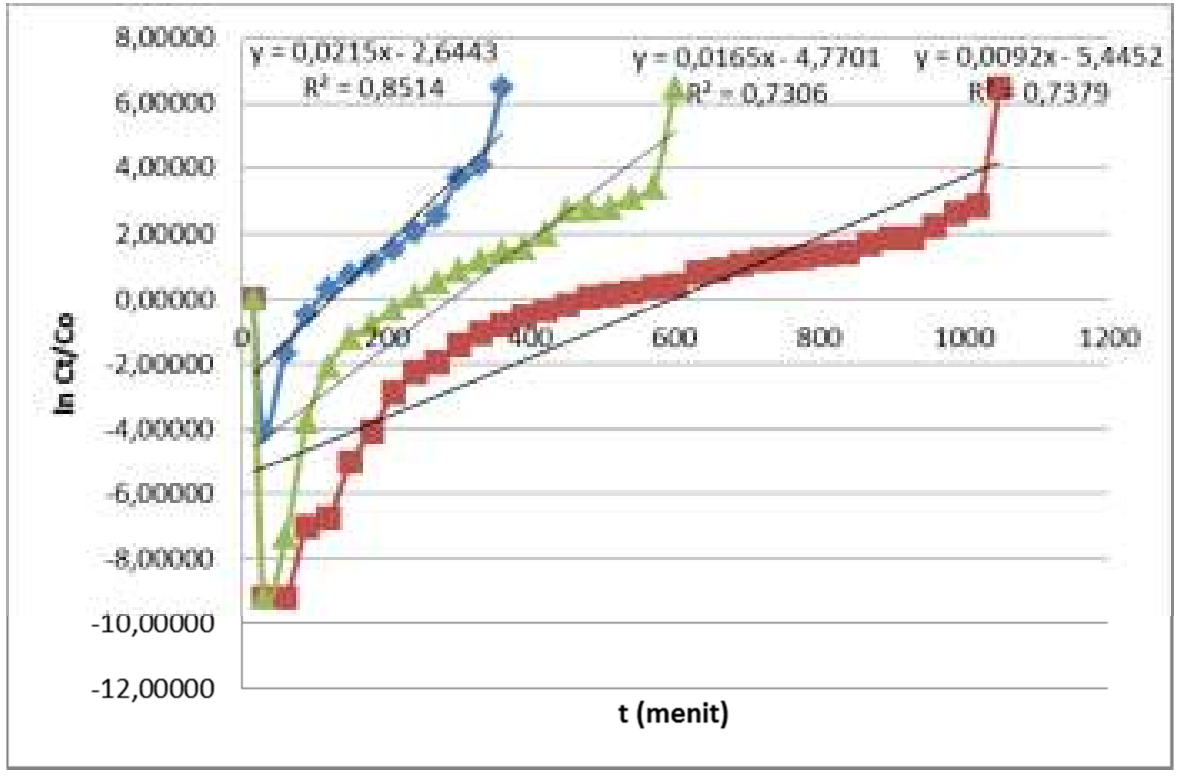

Gambar 7 . Kurva Antara In $\left(C_{t} / C_{o}-C t\right)$ Versus $t$ pada berbagai laju alir

kitosan pada komposit memberikan bentuk yang lebih kokoh sehingga penyusutan yang terjadi lebih kecil. Pada kitosan 3\%, pori yang

terbentuk memiliki panjang sekitar 50$250 \mu \mathrm{m}$. Penyusutan yang terkecil terjadi pada komposit dengan konsentrasi kitosan 3\%, namun dengan bertambahnya konsentrasi kitosan menyebabkan pori yang terbentuk relatif.

\subsection{Analisa Metode Kolum}

\subsubsection{Pengaruh Tinggi Kolum}

Kurva breakthrough pada berbagai ketinggian adsorben ditunjukkan pada gambar 4. Dapat dilihat bahwa dengan semakin tinggi adsorben, waktu untuk mencapai titik jenuh dan jumlah volume effluen yang dihasilkan semakin banyak., Begitu juga dengan efisiensi adsorpsi Esoin $Y$ oleh kitosan hidroksiapatit semakin bertambah. Berbeda dengan slop kurva breakthrough yang semakin kecil dengan semakin bertambahnya tinggi adsorbenKetinggian adsorben sangat mempengaruhi kapasitas adsorpsi. Hasil percobaan menunjukkan bahwa kapasitas adsoprsi 175, 134 and $155 \mathrm{mg} / \mathrm{g}$.Dengan semakin tingginya adsorben, maka luas permukaan semakin bertambah, dan jumlah gugus aktif juga semakin bertambah

\subsubsection{Pengaruh Laju Alir}

Laju alir juga mempengaruhi kapasitas adsorpsi. Pada pertambahan laju alir dari 0,2 $\mathrm{mL} /$ menit menjadi 0,6 $\mathrm{mL} /$ menit kapasitas adsorpsi berkurang dari $250 \mathrm{mg} / \mathrm{g}$ menjadi 112 mg/g. Kurva breakthrough pada berbagai laju alir Eosin $Y$ ditunjukkan pada gambar 5 . Dari gambar 5 dapat dilihat bahwa makin cepat laju alir, makin cepat waktu jenuh. Pertamabahan laju alir dari $0,2 \mathrm{~mL} /$ menit menjadi $0,6 \mathrm{~mL} /$ menit menyebabkan waktu jenuh berkurang dari 440 menit menjadi 160 menit. Jika laju alir semakin cepat, waktu untuk melakukan kontak dengan adsorben semakin cepat, sehingga waktu untuk mencapai titik jenuh semakin cepat dan akibatnya adsorpsi menjadi tidak efisien.

\subsection{Model Kurva Breakthrough}

Beberapa model matematikan telah dikembangkan untuk mendeskripsikan dan menganalisa proses adsorpsi pada. Model model tersebut diantaranya adalah model Thomas, model Adam Bohart dan model Yoon dan Nelson. Pada penelitian ini performan kolum dianalisa dengan nmeggunakan model Yoon dan Nelson. 


\subsubsection{Model Yoon dan Nelson}

Model kinetika Yoon dan Nelson adalah salah satu model kinetika adalah salah satu model kinetika yang dikembangkan untuk mengkaji proses adsorpsi heterogen dalam sistem yang mengalir. Model Yoon dan Nelson merupakan model yang paling umum dan banyak digunakan untuk mengkaji kurva breakthrough karena kesederhanaannya (Han dkk, 2007). Model kinetika Yoon dan Nelson dinyatakan dengan persamaan:

$$
\ln \frac{C_{t}}{C_{o}-C_{t}}=k_{Y N} \cdot t-\tau \cdot k_{Y N}
$$

Keterangan: $\quad C_{t} \quad=$ konsentrasi efluen yang keluar dari kolom $(\mathrm{mg} / \mathrm{L})$

$$
\mathrm{C}_{\mathrm{o}} \quad=\text { konsentrasi larutan }
$$

awal sebelum masuk kolom ( $\mathrm{mg} / \mathrm{L}$ )

$$
\mathrm{t} \quad=\text { laju alir volumetric }
$$

(L/menit)

$\left(\right.$ menit $\left.^{-1}\right)$

$$
\mathrm{k}_{\mathrm{YN}} \quad=\text { tetapan kinetik }
$$

$$
\tau \quad=\text { waktu yang }
$$

diperlukan untuk 50\% adsorbat pecah (menit)

Model Yoon dan Nelson dapat diubah menjadi bentuk persamaan linear seperti pada persamaan di atas sehingga dapat digunakan untuk mengolah data kurva breakthrough menggunakan cara regresi linear yang sederhana, dimana $\ln \left(\mathrm{C}_{\mathrm{t}} / \mathrm{C}_{0}-\mathrm{C}_{\mathrm{t}}\right)$ sebagai ordinat atau sumbu y dan $\mathrm{t}$ sebagai absis atau sumbu $x$. Koefisien regresi linear $r^{2}$ harus berada pada interval 0,9-1,0. Dari regresi linear akan diperoleh persamaan linear $y=a+$ bx, dimana a adalah intercept dan b adalah gradient. Berdasarkan nilai intercept a dapat dihitung kapasitas adsorpsi $\mathrm{q}_{\mathrm{o}}$ dan dari nilai gradient dapat dihitung tetapan laju Yoondan Nelson $k_{\mathrm{YN}}$. Gambar 6 dan gambar 7 masing masing menunjukkan kurva antara In $\left(\mathrm{C}_{\mathrm{o}} / \mathrm{C}_{\mathrm{o}}-\mathrm{C}_{\mathrm{t}}\right.$ ) versus $t$ pada berbagai tinggi adsorben dan berbagai laju alir

Dari grafik tersebut didapat persamaan garis linear. Dan sesuai dengan persamaan Yoon dan Nelson dapat dihitung nilai $q_{o}$ dan $\mathrm{k}_{\mathrm{YN}}$ untuk tiap laju alir dan tinggi adsorben. Berikut ini tabel yang menyatakan nilai $\mathrm{k}_{\mathrm{Th}}$ dan $\mathrm{q}_{\mathrm{o}}$.

Terlihat dari tabel di atas, nilai $k_{Y N}$ berbanding terbalik dengan $\mathrm{q}_{\mathrm{o}}$. Semakin besar nilai $k_{\mathrm{YN}}$ maka semakin kecil nilai $\mathrm{q}_{\mathrm{o}}$. Hasil penelitian juga menunjukkan bahwa semakin tinggi adsorben, semakin besar nilai $q_{0}$, sebaliknya semakin kecil laju alir, nilai $\mathrm{q}_{0}$ semakin besar. Dengan tinggi adsorben $0,3 \mathrm{~cm}$ dan laju alir $0,2 \mathrm{~mL} /$ menit diperoleh nilai $\mathrm{q}_{\circ}$ $99,62 \mathrm{mg} / \mathrm{g}$

\section{Kesimpulan}

Dari hasil percobaan dapat disimpulkan bahwa hidroksiapatit dapat diperoleh dengan mereaksikan $500 \mathrm{~mL} \mathrm{Ca}(\mathrm{OH})_{2}$ 0,6 $\mathrm{M}$ dengan $500 \mathrm{~mL} \mathrm{H} \mathrm{PO}_{4}$ dalam suasana basa $(\mathrm{pH}=10)$ .Selanjutnya hisroksiapatit dimasukkan kedalam larutan kitosan, sehingga terbentuk kitosan hidroksiapatit. Pembentukan kitosan hidroksiapatit terbentuk melalui ikatan antara gugus fosfat dari hidroksiapatit dengan gugus amina dari kitosan. Sebagai adsorben hidroksiapatit telah digunakan untuk mengadsorpsi larutan Eosin $Y$ dengan menggunakan metode kolum. Kapsitas adsorpsi sebesar diperoleh pada kondisi laju alir Eosin Y 0,2 mL/menit dan tinggi adsorben $0,4 \mathrm{~cm}$. Model Yoon dan Nelson menunjukkan kesesuaian kurva breaktrhough antara hasil percobaan dengan hasil prediksi.

\section{Daftar Pustaka}

[1] Crini, G., \& Badot, P. M. 2008. Application of chitosan, a natural aminopolysaccharide, for dye removal from aqueous solution by adsorption process using batch studies: A review of recent literature. Progress in Polymer Science, 33, 399-447. 
[2] Lourenco.N.D, J.M. Novais, H.M. Pinheiro.2003., Reactive textile dye colour removal in a sequencing batch reactor, Water Science and Technology 42: 321-328.

[3] Pearce, C.I., Lloyd, J.R., Guthrie, J.T., 2003. The removal of colour from textile wastewater using whole bacterial cells: a review. Dyes Pigm. 58:179-196.

[4] Crini.G.2006. Non conventional low cost adsorbent for dye removal; a review Bioresour.Technol. 97 : 1061-1085

[5] Dotto.G.L., and Pinto, L.A.A. Pinto,2011,Adsorption of food dyes onto chitosan: Optimization process and kinetic,Carbohydrate Polymer 84 :231-238.

[6] Gurses, A., Karaca, S., Dogar, C., Bayrak, R., Acikyildiz, M., Yalcin, M., 2004. Determination of adsorptive properties of clay/water system: methylene blue sorption. J. Colloid Interface Sci. 269: 310-314.

[7] Cheung .W.H; Y.S. Szeto, G. McKay.2009 Enhancing the adsorption capacities of acid dyes by chitosan nano particles. Bioresource Technology 100: 1143-1148

[8] Chen Yuwei, Wang Jianlong.2011. Preparation and characterization of magnetic chitosan nanoparticles and itsnapplication for $\mathrm{Cu}(\mathrm{II})$ removal. Chemical Engineering Journal 168: 286-292

[9] Raziyeh Salehia, Mokhtar Aramia, Niyaz Mohammad Mahmoodi,mHajir Bahramia, Shooka Khorramfara.2010.Novel biocompatible composite (Chitosan-zinc oxide nanoparticle): Preparation,characterization and dye adsorption properties.Colloids and Surfaces $B$ : Biointerfaces 80: 86-93

[10] Kousalyaa.N, Muniyappan Rajiv Gandhi, C. Sairam Sundaram, S. Meenakshi.2009. Synthesis of nano-hydroxyapatite chitin/chitosan hybrid biocomposites for the removal of $\mathrm{Fe}(\mathrm{III})$. Carbohydrate Polymers 82 : 594-599

[11] Peng Yuan, Mingde Fana, Dan Yanga, Hongping Hea, Dong Liua, Aihua Yuan , JianXi

[12] Zhua, TianHu Chen.2009. Montmorillonite-supported magnetite nanoparticles for the removalof hexavalent chromium $[\mathrm{Cr}(\mathrm{VI})]$ from aqueous solutions. Journal of Hazardous Materials 166 : 821-829

[13] Jesus Barron-Zambrano , Agata Szygula , Montserrat Ruiz, Ana Maria Sastre , Eric Guib.2010. Biosorption of Reactive Black 5 from aqueous solutions by chitosan: Column studies. Journal of Environmental Management 91: 2669-2675

[14] Cybelle Morales Futalan, Chi-Chuan Kan, Maria Lourdes Dalida, Chelo Pascua, Meng-Wei Wan. Fixed-bed Column Studies on the Removal of Copper Using Chitosan Immobilized on Bentonite.Carbohydrate Polymer

[15] Iman Kavianiniaa, Paul G. Plieger, Nadia G. Kandileb, David R.K. Harding.2012. Fixed-bed column studies on a modified chitosan hydrogel for detoxification of aqueous solutions from copper (II). Carbohydrate Polymers 90: 875- 886

[16] Suhong Chen, Qinyan Yue, Baoyu Gao, Qian Li, Xing Xu, Kaifang Fu.2012. Adsorption of hexavalent chromium from aqueous solution by modified corn stalk: $A$ fixed-bed column study. Bioresource Technology 113 : 114-120

[17] Aksu, Z., Gönen, F., 2004. Biosorption of phenol by immobilized activated sludge in a continuous packed bed: prediction of breakthrough curves. Process Biochem. 39, 599-613 